\title{
BAGOSSY MÁRIA
}

\section{A büntetőjogi szankció korlátai az alkotmányjogban és a nemzetközi jogban}

A szabadságvesztés és a kínzás tilalma ${ }^{1}$

Nagy Ferenc szerint a büntetöjogi szankció olyan törvényben meghatározott joghátrány, amelyet fő szabályként a bíróság (két esetben az ügyész) büncselekmény, illetve jogellenes cselekmény elkövetöjével szemben a társadalom védelme, a bünelkövetéstől való visszatartás érdekében, kizárólag törvényben meghatározott feltételekkel és eljárásban alkalmaz, és amelyet az állam adott esetben kényszer útján is érvényesíthet. ${ }^{2} \mathrm{~A}$ büntetőjogi szankció ultima ratio eszköz, kiszabására, alkalmazására csak végső esetben kerülhet sor. A jogállamiság eszméjéből következően azonban nem elegendő pusztán az ultima ratio jelleg érvényesülése, a büntetőjogi szankcionálást további korlátok közé kell szorítani. Ezt az elvárást támasztja az alaptörvény, valamint számos nemzetközi jogi instrumentum is, amelyek megsértése bíráló hangvételü jelentésektöl a pénzbeli kártérítésig terjedö következményeket vonhat maga után. Csak példálózó felsorolást adva e korlátokról: nulla poena, sine lege $e^{3}$, ne bis in idem ${ }^{4}$, élethez való jog. ${ }^{5}$

Jelen tanulmány keretében azt kívánom vizsgálni, miként érvényesül egy ilyen korlát, mégpedig a kínzás és az embertelen, megalázó bánásmód tilalma a szabadságvesztés-büntetés végrehajtása során. ${ }^{6}$ Mind az alaptörvény, mind az Emberi jogok európai egyezménye kimondja, hogy senkit sem lehet kínzásnak vagy embertelen, megalázó bánásmódnak vagy büntetésnek alávetni. ${ }^{7}$ E tilalomba ütközik a tényleges életfogytig tartó szabadságvesztés hatályos szabályozása ${ }^{8}$, a különösen veszélyes elítéltek izolált elhelyezése", vagy a fogvatartottak, különösen a fogyatékkal élők részére biztosított egészségügyi ellátás nem megfelelő volta. ${ }^{10} \mathrm{~A}$ szabadságvesztés-büntetés vonatkozásában a legföbb problémát mégsem ezek, hanem az elhelyezési körülmények, elsősorban a jogszabályban előírt élettér biztosításának hiánya okozza. A következőkben - a kapcsolódó jogszabályi háttér és az Emberi Jogok Európai Bírósága ítélkezési gyakorlatának bemutatása után - ismertetem azokat a módszereket, amelyek megoldást kínálhatnak a magyar büntetés-végrehajtási intézetek telítettségének enyhítésére, illetve megszüntetésére. 


\section{A hazai büntetés-végrehajtás zsúfoltsága}

A büntetés-végrehajtási intézetek telítettsége nem új keletü jelenség, noha egészen az 1990-es évek elejéig csupán „látens” módon jelentkezett, ugyanis a Büntetés-végrehajtási Szabályzat végrehajtásáról szóló 101/1981. (IK. 2.) IM utasítás még hat-nyolc köbméter mozgásteret írt elő a fogvatartottak számára, ez az épületek nagy belmagassága miatt kedvezőnek mutatta a kapacitási adatokat. Amikor azonban 1990. május 31-én a 6/1990. (IK. Bv. Mell. 1.) IM utasítás bevezette az európai börtönügyi ajánlásokban is használatos $\mathrm{m}^{2} /$ fö mértékegységet és ennek megfelelően határozták meg az elhelyezhető létszámot, kiderült, hogy a magyar büntetés-végrehajtási rendszer kapacitásbeli gondokkal küszködik. ${ }^{11}$ Ennek orvoslására született meg a büntetés-végrehajtás intézetrendszerének hosszú távú fejlesztéséről szóló 2072/1998. (III. 31.) kormányhatározat, amely az 1999 és 2007 közötti időszakra új férőhelyek létesítését és a meglévők korszerüsítését irányozta elö. ${ }^{12}$ Ezáltal a féröhelyek átlagos száma 2011-re már 12335 fő lett az 1994-es 10459 fővel szemben. A büntetés-végrehajtási intézetek átlagtelítettségét, valamint az átlagos befogadóképesség és a fogvatartotti létszám alakulását az 1. és a 2. számú ábra szemlélteti. ${ }^{13}$

Több nemzetközi szervezet már 2011 elött is felhívta a figyelmet a bv. intézetek túlzsúfoltságára ${ }^{14}$, az erre hivatkozó fogvatartotti kérelmek elfogadhatóságáról azonban először 2011-ben döntött az Emberi Jogok Európai Bírósága és hozott marasztaló ítéletet hazánkkal szemben. ${ }^{15}$ A Szél kontra Magyarország-ügyben a magyar állam védekezése arra épült, hogy a fogvatartott az elhelyezés körülményei miatt nem élt panasszal sem a büntetésvégrehajtási szerveknél, sem pedig a törvényességi felügyeletet ellátó ügyésznél, ezáltal nem merítette ki a rendelkezésére álló jogorvoslati lehetőségeket. ${ }^{16} \mathrm{~A}$ bíróság megállapította, hogy a hatóságok tisztában voltak a börtönökben uralkodó állapotokkal, valamint a fogvatartott elhelyezéséröl gondoskodó Budapesti Fegyház és Börtönben az átlagos telítettség elérte a százötven százalékot, ezért a kérelmező hiába élt volna bármelyik említett lehetőséggel, számottevő változásra nem számíthatott. ${ }^{17} \mathrm{Az}$ ítélet hivatkozott az Európa Tanács Kínzás Elleni Bizottsága (Committee for the Prevention of Torture, a továbbiakban: CPT) által elvárt személyenkénti négy négyzetméter standardra is ${ }^{18}$, amihez képest a kérelmezőnek huszonegy hónapig 2,76, további huszonegy hónapig 3,15, kilenc hónapig pedig 3,125 $\mathrm{m}^{2}$ mozgástérrel kellett beérnie a különböző zárkákban. Ezzel a kérelmező emberi méltósága és az EJEE 3. cikke sérelmet szenvedett. ${ }^{19}$ 
1. számú ábra

A büntetés-végrehajtási intézetek átlagtelítettsége (1994-2017; \%)

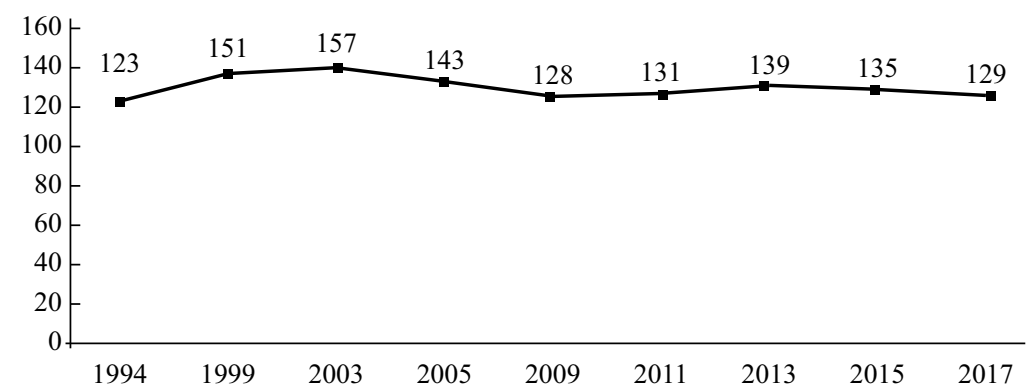

2. számú ábra

A bv. intézetek átlagos befogadóképességének és a fogvatartottak átlaglétszámának alakulása (1994-2017)

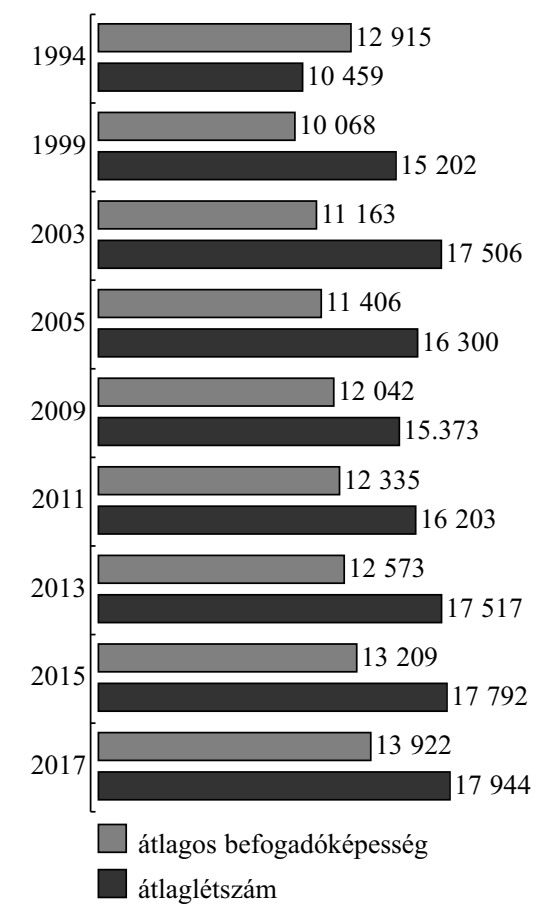


Hasonlóan végződött a Kovács Gábor István kontra Magyarország-ügy is, amelynek kérelmezője a Szegedi Fegyház és Börtönben töltötte szabadságvesztés-büntetését. Mivel az átlagosan $16 \mathrm{~m}^{2}$-es cellákban öt-hét ember raboskodott, ez esetben sem teljesült a CPT elvárása, továbbá a fogvatartottak mindössze napi egy órára hagyhatták el a zsúfolt zárkákat. A bíróság a Szél kontra Magyarország-ügyben kimondottakra hivatkozva elfogadhatónak minősítette a kérelmet, és kártérítést szabott ki. ${ }^{20}$

Ítéleteiben az EJEB felhívta a figyelmet arra, hogy a túlzsúfoltság hatékony megoldásához meg kell tenni a szükséges jogi, adminisztratív és gyakorlati intézkedéseket, továbbá a hatóságoknak sürgősen lépniük kell annak érdekében, hogy megteremtsék a fogvatartottak megfelelö körülmények között való elhelyezését. Az első lépést a magyar Alkotmánybíróság tette meg, amikor is a 32/2014. (XI. 3.) számú határozatával megállapította a 6/1996. (VII. 12.) IM rendelet 137. § (1) bekezdésének az Emberi jogok európai egyezményébe és az alaptörvénybe ütközését. Az IM-rendeletet ugyanis a 12/2010. (XI. 9.) KIM rendelet 2010. november 24-i hatállyal úgy módosította - a CPT 2013-as jelentésében is bíráltan,$-{ }^{21}$ hogy a fogvatartottak számára biztosítandó mozgástér minimális mértékére vonatkozó kógens szabályozás helyett a következőt rögzítette: „A zárkában (lakóhelyiségben) elhelyezhetö létszámot úgy kell meghatározni, hogy minden elitéltre lehetöleg hat köbméter légtér, és lehetöség szerint a férfi elitéltek esetén három négyzetméter, a fiatalkorúak, illetve a női elitéltek esetén három és fél négyzetméter mozgástér jusson." Az Alkotmánybíróság megállapította, hogy az embertelen és megalázó bánásmód tilalmából következően a jogalkotó kötelezettsége, hogy kógens jelleggel szabályozza a fogvatartottak élet- és mozgásterének olyan minimális mértékét, amely még az emberi méltósághoz való joguk sérelme nélküli elhelyezésüket teszi lehetővé. 22

A testület határozatának meghozatala során ,hangsúlyozottan irányadónak" tekintette az EJEB joggyakorlatát az EJEE 3. cikkével kapcsolatban. Az $\mathrm{AB}$ a kezdeményezett eljárás, azaz a nemzetközi szerződésbe ütközés vizsgálatának szükségessége mellett azért is fordított kiemelt figyelmet a strasbourgi bíróság ítéleteire, mert a kínzás és az embertelen, megalázó bánásmód tilalmának részletes kifejtésével korábbi döntéseiben nem foglalkozott. ${ }^{23} \mathrm{Az}$ Alkotmánybíróság 2015. március 31-i hatállyal kívánta megsemmisíteni az említett bekezdést, időt hagyva a jogalkotónak az Emberi jogok európai egyezményével és az alaptörvénnyel összhangban álló jogszabályi rendelkezés kidolgozására, időközben azonban a 6/1996. (VII. 12.) IM rendeletet 2015. január 1-jével hatályon kívül helyezte a szabadságvesztés, az elzárás, 
az előzetes letartóztatás és a rendbírság helyébe lépő elzárás végrehajtásának részletes szabályairól szóló 16/2014. (XII. 19.) IM rendelet. ${ }^{24}$ A jogalkotó eleget téve az Alkotmánybíróság határozatában foglaltaknak, kógens jelleggel rögzítette a rendeletben, hogy férfi elítélt esetén legalább három, női elítélt és fiatalkorú esetén három és fél négyzetméter mozgástérről kell gondoskodni. ${ }^{25}$

Az alkotmánybírósági eljárással egyidejüleg zajlott az EJEB hazánkkal szemben kezdeményezett első pilot judgment eljárása, a Varga és mások kontra Magyarország-ügy. ${ }^{26} \mathrm{Az}$ eljárás hat kérelmezője külőnbőző magyarországi bv. intézetben töltötte előzetes letartóztatását vagy szabadságvesztésbüntetését. Az EJEB áttekintette a magyar bv. rendszerre vonatkozó nemzetkőzi és belső jogi dokumentumokat, így az Európa Tanács Miniszteri Bizottsága több ajánlását, a CPT legutóbbi, 2013-as jelentését, az alapvető jogok biztosának a kérelmezők elhelyezésére szolgáló bv. intézetekben tett látogatásairól készült jelentéseit, valamint a hazai bírósági esetjogot. A korábbi ítéleteihez hasonlóan jelen ügyben is azt állapította meg, hogy nem állt a kérelmezők rendelkezésére hatékony jogorvoslat, amellyel az elhelyezési körülményeiket sérelmezhették volna. Ezen túlmenően a négy négyzetméternél kisebb mozgástér, amely kiegészült olyan további negatívumokkal, mint a zárkák leromlott állapota, a le nem választott mosdóhelyiségek, a nem megfelelő szellőzés és világítás, megalázó bánásmódnak minősült. A pilot judgment eljárás jellegéből fakadóan ítéletében az EJEB megoldási javaslatokkal is élt: bár nem a bíróság feladata a tagállamok büntetőpolitikájának a meghatározása, a túlzsúfoltság csökkentésének módja lehet a szabadságelvonással nem járó szankciók szélesebb körü alkalmazása, valamint az előzetesen letartóztatottak számának csökkentése. ${ }^{27}$

A Varga és mások kontra Magyarország pilotítélet, valamint a 32/2014. (XI. 3.) AB határozat után radikális fordulat következett be a hazai bíróságok gyakorlatát illetően, ennek első jele a Kúria Pfv.IV.21.654/2015/11. számú döntése volt. Az első- és a másodfokú bíróság is elutasította a felperes nem vagyoni kártérítés iránti keresetét, amelyet az elhelyezésére szolgáló büntetés-végrehajtási intézet 178 százalékos túlzsúfoltságára és a számára biztosított elégtelen mozgástérre hivatkozással igényelt. A bíróságok arra az álláspontra helyezkedtek, hogy - ahogyan azt a korábban már említett döntvények is megerősítették - az állandó bírói gyakorlat szerint a büntetés-végrehajtási intézet a börtönviszonyok objektív körülményeiért nem tehető felelőssé, nincs mérlegelési joga az elítéltek befogadását illetően. A felülvizsgálati eljárásban a Kúria ezzel szemben rögzítette, hogy amennyiben a büntetés-végrehajtási intézet a vonatkozó IM-rendeletben meghatározott ${ }^{28}$, a fogva tartás so- 
rán irányadó kötelezettségét nem teljesíti, azzal felróható magatartást tanúsít. Ebből következően az önálló jogalanyiságú büntetés-végrehajtási intézet a fogvatartottakat az intézetben érö sérelmek miatt kártérítési felelősséggel tartozik.

A Kúria ítélete után például a Pécsi Ítélőtábla Pf.VI.20.023/2016/4. számú határozata már úgy fogalmaz, hogy az EJEB ítéletei nyomán megváltozott a hazai bírói gyakorlat a büntetés-végrehajtási intézetekben tapasztalható túlzsúfoltság, illetve a kimentés megítélése körében. A büntetés-végrehajtási intézet a befogadási kötelezettségére hivatkozással nem mentesülhet a felelősség alól, hiszen a jogszabályok betartása, a fogvatartottak megfelelö elhelyezéséröl való gondoskodás ugyancsak kötelessége. Számos ítélőtáblai másodfokú határozat ehhez hasonlóan rendelkezett a korábbi gyakorlatnak megfelelően született elsőfokú határozatok megváltoztatásáról ${ }^{29}$, illetve már olyan elsőfokú ítéleteket is találhatunk, amelyek az újabb esetjogra hivatkozással helyt adtak a fogvatartotti kereseteknek..$^{30}$

Noha a piloteljárás nyomán a fogvatartotti kárigények tekintetében - a fogvatartottak számára kedvező módon - megváltozott a hazai bírósági gyakorlat, azonban arra nem került sor, hogy ennek mint kompenzációs jogorvoslati lehetőségnek az EJEE 13. cikkével való összeegyeztethetőségét az Emberi Jogok Európai Bírósága megvizsgálja. A jogalkotó ugyanis 2017. január 1-jei hatállyal bevezette az alapvető jogokat sértő elhelyezési körülmények miatti panasz-, illetve kártalanítási eljárást, amelyek immár megteremtik a fogvatartottak számára a bíróság által megkívánt preventív, illetve kompenzációs jogorvoslati lehetőségeket. A bv. kódex 2016. évi CX. törvénnyel történő módosításai kapcsán az EJEB a Domján kontra Magyarország-ügyben akként foglalt állást, hogy az EJEE 13. cikke értelmében az új eljárások olyan hatékony jogorvoslati eszközöknek minősülnek, amelyeket a fogvatartottaknak ki kell meríteniük az előtt, hogy kérelmüket a strasbourgi bírósághoz benyújtanák. ${ }^{31}$

\section{Megoldási módszerek}

A pilot judgment eljárás után a bírósági gyakorlatban történtő fordulat, majd az alapvető jogokat sértő elhelyezési körülmények miatti panasz- és kártalanítási eljárás bevezetése az EJEE 13. cikkével kapcsolatban feltárt strukturális problémák orvoslására szolgált. Mindezekkel párhuzamosan a magyar kormány elkezdett megoldást keresni az egyezmény 3. cikkének hatálya alá 
tartozó jogsértés, azaz a hazai büntetés-végrehajtási intézetek túlzsúfoltságának enyhítésére is. A kormányzat új börtönök építését irányozta elö, azonban a kapcsolódó nemzetközi ajánlások a férőhelybővítés helyett (de legalábbis mellett) más megoldási javaslatokat is kínálnak.

\section{Börtönépítés}

A kormány által meghirdetett férőhelybővítési program keretében 2019-ig nyolc új börtön építésére kerül(ne) sor hazánkban. ${ }^{32}$ A kialakítandó nagyjából hatezer férőhely megszüntetné a büntetés-végrehajtási intézetek túlzsúfoltságát, ezzel elejét venné az emberi méltóságot sértő elhelyezési körülmények miatti kártalanítási igényeknek. Azonban ahogyan arra a Magyar Helsinki Bizottság is rámutatott, a szigorú és szabadságvesztés-centrikus büntetőpolitika következtében 2019-ig ütemesen nőhet a fogvatartottak száma ${ }^{33}$, így a féröhelybővítés nem valódi megoldás a telítettség problémájára, azt sokkal inkább a fogvatartotti létszám csökkentésével, alternatív büntetések alkalmazásával lehetne orvosolni. Ezt igazolja az az egyszerü tény is, hogy miközben a börtönök zsúfoltsága az utóbbi húsz évben kisebb eltérésekkel, de folyamatosan százharminc-száznegyven százalék körül mozog, addig a regisztrált büncselekmények számában különösen az utóbbi öt évben számottevő csökkenés volt megfigyelhetö (3. számú ábra) ${ }^{34}$.

A börtönök megépítéséig az államot továbbra is terheli a fogvatartottakkal szembeni kártalanítási kötelezettség. Gondot okoz azonban, hogy előbb a Csenger, Heves, Kemecse, Ózd ${ }^{35}$, majd a Komló, Komádi, Békés, Kunmadaras településeken építendő büntetés-végrehajtási intézetek kivitelezésére kiírt pályázatok is eredménytelenül zárultak. ${ }^{36} \mathrm{~A}$ helyzet ezáltal csak egy ponton

3. számú ábra

Regisztrált büncselekmények száma (1990-2017; db)

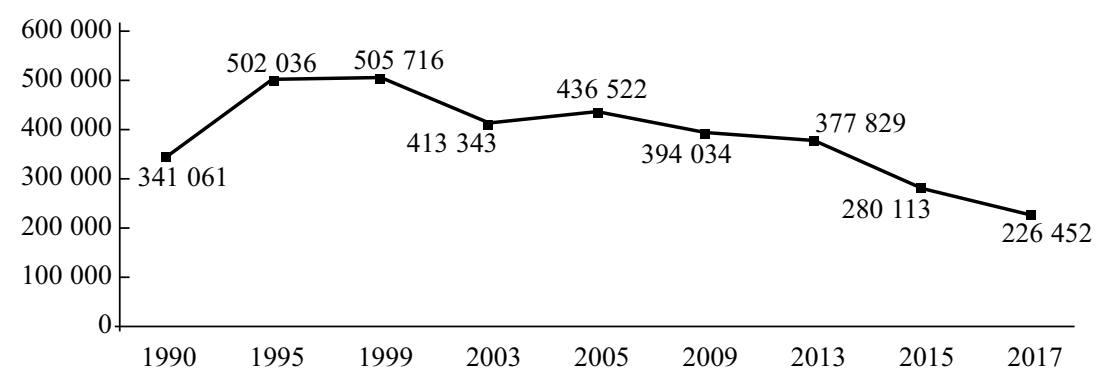


változott: az Emberi Jogok Európai Bírósága helyett a magyar bíróságok részesítik kártalanításban a fogvatartottakat.

\section{A büntetőpolitika enyhítése}

Ahogyan arra az Európai Börtönszabályok preambuluma rámutat ${ }^{37}$, senkit sem lehet szabadságától megfosztani, kivéve, ha a szabadságelvonást végső eszközként alkalmazzák, és az összhangban áll a törvényekben meghatározott eljárásokkal. Ez az ajánlás, szemben a jelenlegi szabadságvesztés-centrikus hazai büntetőpolitikával, előnyben részesítené az olyan szabadságelvonással nem járó büntetéseket, mint például a közérdekü munka vagy a

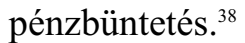

A jogerősen kiszabott végrehajtandó szabadságvesztések az összes fö büntetés 13 százalékát tették ki 2016-ban. ${ }^{39}$ Noha ez nem tünik soknak, Magyarország mégis az élmezőnyben van a százezer lakosra jutó fogvatartottak - a szabadságvesztésüket töltő személyek mellett a letartóztatottak is - számát tekintve az Európa Tanács tagállamai között. ${ }^{40}$ Ennek az arányszámnak, azaz a fogvatartotti rátának az utóbbi évtizedekben történő alakulását a 4. számú ábra mutatja. A 180,8-es mutató annak fényében aggályos, hogy a hazánkat megelőző tizenkét állam közül csak négy nem tud négy négyzetméternyi mozgástérről gondoskodni a szabadságuktól megfosztott személyek számára ${ }^{41}$ Ha pedig nem a CPT standardját, hanem az EJEB által elvártakat alkalmazzuk, a helyzet még rosszabb, hiszen az említett négy állam mindegyikében az egy fogvatartottra jutó mozgástér eléri a három négyzetmétert. ${ }^{42}$ Magyarországon ez mindössze 2,8 négyzetméter, amellyel az utolsó helyet foglaljuk el az Európa Tanács tagállamai között. ${ }^{43}$ A kiugró fogvatartotti ráta önmagában azonban nem jelenti azt, hogy egy ország bv. rendszere túlterhelt lenne, így például Albániában százezer lakosra 207,2 fogvatartott jut, ennek ellenére az állam mozgástérre vonatkozó mutatója személyenként 5,3 négyzetméter. $^{44}$

A fogvatartotti ráta alakulása több okra vezethető vissza. Így a rendszerváltás és az ezzel járó politikai, társadalmi, gazdasági átalakulás után a börtönnépesség az amnesztiák következtében csökkent, majd a bünözés erőteljes növekedésével ismételten emelkedni kezdett. ${ }^{45}$ A 2002 és 2010 közötti időszakban bekövetkező csökkenés véleményem szerint egyértelmủen összefüggésbe hozható azzal, hogy 2003. március 1-jével a 2003. évi II. törvény hatályon kívül helyezte a régi Btk. középmértékes büntetéskiszabásra vonat- 
A fogvatartotti ráta alakulása (1980-2016; \%)

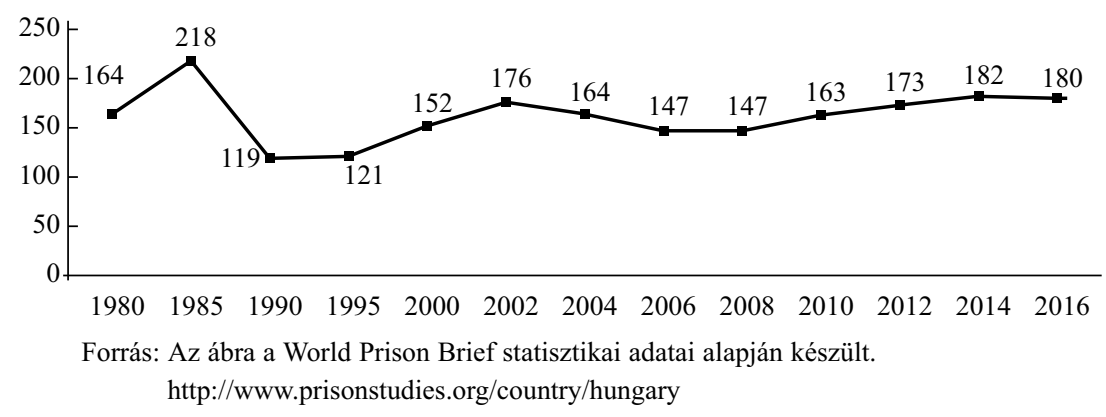

kozó rendelkezését, valamint a feltételes szabadságra bocsátás és a szabadságvesztés végrehajtása felfüggesztésének lehetőségével kapcsolatos több kizáró okot is.$^{46} \mathrm{E}$ módosításokat a jogalkotó - nézetem szerint helyesen - azzal indokolta, hogy a büntetések szigorításától nem várható a bünözés hatékonyabb visszaszorítása, célkitüzésként pedig meghatározta, hogy a bíróságok csak abban az esetben szabjanak ki végrehajtandó szabadságvesztést, ha a Btk.-ban foglalt büntetési célok más büntetéssel nem érhetők el. ${ }^{47}$

A 2009. évi LXXX. törvény által érvényesített kettős nyomtávú büntetőpolitikától elszakadva a három csapás néven ismertté vált 2010. évi LVI. törvény kizárólag a szigorítás irányába haladt tovább annak ellenére ${ }^{48}$, hogy a regisztrált büncselekmények száma 2005 óta folyamatosan csökkent. ${ }^{49} \mathrm{~A}$ törvény újból bevezette a középmértékes büntetést, szigorította a bünismétlők és a bünhalmazat esetén kiszabható büntetéseket.

Ennek az egyre szigorodó kriminálpolitikának a következményeként született meg a 2012. évi C. törvény is, amely az elterelés és az alternatív szankciók irányvonala helyett a megtorlást és a szabadságvesztés-centrikus szankcionálást részesítette előnyben. ${ }^{50} \mathrm{~A}$ fogvatartotti létszámot tekintve a jogszabályi háttér megváltozása öt-hét év után csapódik le ${ }^{51}$, ezért ha megvizsgáljuk a 2003. évi II. törvény és a 2010. évi LVI. törvény, valamint az új Btk. által fémjelzett időszakokat, szembetűnő a különbség. 2008-ban „mindössze" 118 százalékos volt a magyar bv. intézetek átlagos zsúfoltsága, és a fogvatartotti ráta is 147-et mutatott. 2013-ban már 143, 2014-ben pedig 141 százalék volt az átlagtelítettség. A legújabb adatok 2017-re vonatkozóan 129 százalékos zsúfoltságot jeleznek, a megelőző évekhez képest azonban legföképp annak nyomán csökkent ez a szám 129 százalékra, hogy több bv. intézetben is féröhelybővítések történtek. ${ }^{52}$ 
A szigorú hazai büntetőpolitikát jelzi a hosszú időtartamú, azaz az ötévi vagy ennél hosszabb szabadságvesztések nagy száma is (5. számú ábra).

5. számú ábra

A hosszú időtartamú szabadságvesztések számának alakulása (2000-2015; db)

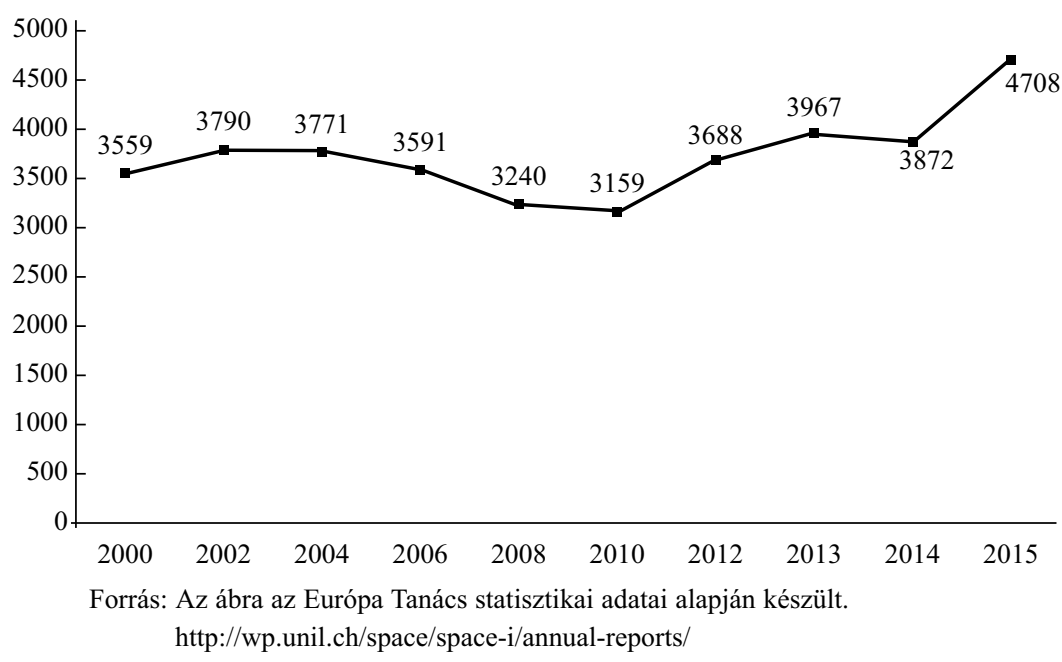

Csóti András szerint az átlagtelítettségben bekövetkező emelkedés nem elsősorban a büntetőpolitikai változások folyománya, a hazai börtönnépesség száma azoktól függetlenül is jelentősen emelkedik. ${ }^{53}$ Elfogadva véleményét, valamint visszautalva arra, hogy a börtönnépesség száma több tényező, így a büntetőpolitika irányvonala mellett a társadalmi, gazdasági hatások függvényében is változik, úgy gondolom, egyértelmüen megállapítható a szigorú büntetőpolitika és a bv. intézetek telítettsége, a fogvatartotti ráta, valamint a hosszú időtartamú szabadságvesztésre ítéltek száma közötti összefüggés. Ebböl következően, ahogyan azt a 2003. évi II. törvény is jól mutatja, a zsúfoltság enyhítésének járható és igen hatékony útja a kriminálpolitika enyhítése.

\section{A letartóztatottak számának csökkentése ${ }^{54}$}

Ahogyan a szabadságvesztés esetében, úgy a letartóztatás elrendelésekor is azt az alapelvet kell figyelembe venni, hogy az ítélethozatal előtti fogva tartás kivételes intézkedés, sohasem lehet kötelezö, és csak abban az esetben alkalmazható, ha a körülmények feltétlenül szükségessé teszik. ${ }^{55}$ Ennek ellené- 
re, amint az a 6. számú ábrán is jól látható, a letartóztatottak a teljes fogvatartotti létszám átlagosan húsz-huszonöt százalékát teszik ki.

6. számú ábra

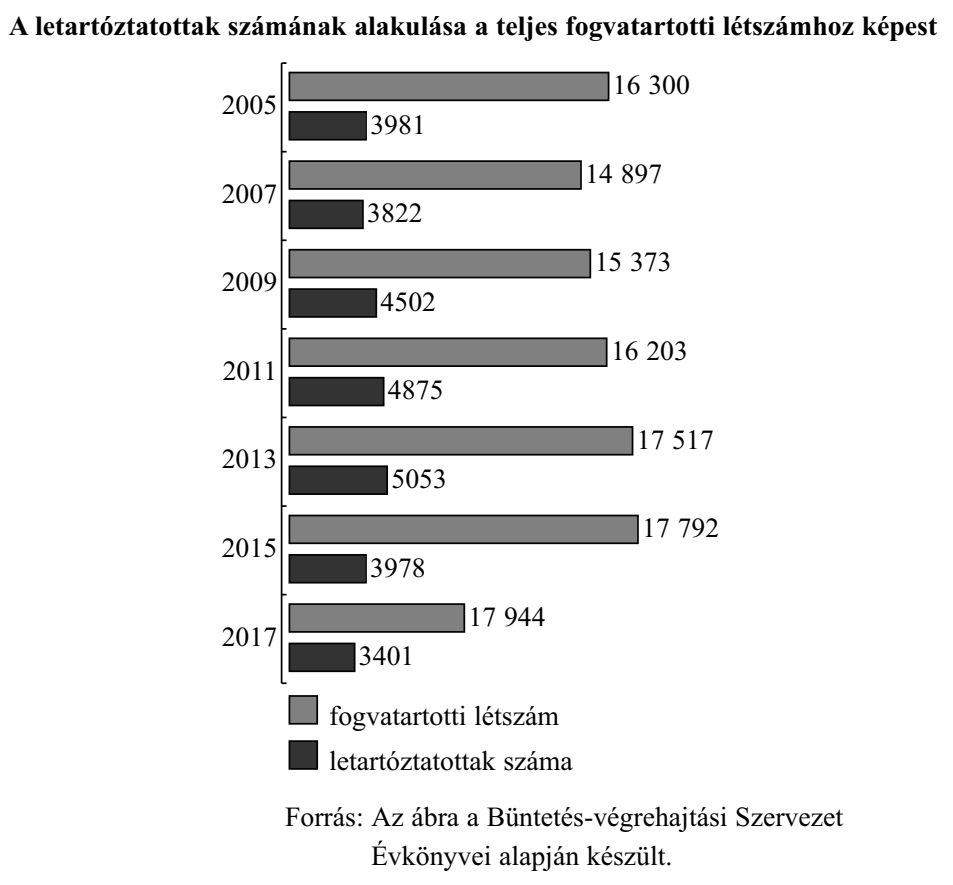

A letartóztatottak helyzetét illetően nemcsak a valamennyi fogvatartottat sújtó zsúfoltság okoz nehézséget, hanem a kényszerintézkedés elrendelésének és meghosszabbításának indokoltsága is. Ezzel kapcsolatban a hazai szakirodalomban sincs egyetértés, vajon a bíróságok eleget tesznek-e indokolási kötelezettségüknek, vagy pusztán mechanikusan megismétlik a kényszerintézkedés valamely különös feltételére vonatkozó törvényszöveget. ${ }^{56} \mathrm{~A}$ letartóztatás helyett rendelkezésre álló kényszerintézkedések gyakoribb alkalmazása mellett szóló érv az is, hogy az Emberi Jogok Európa Bírósága számos esetben elmarasztalta hazánkat az észszerütlenül hosszú ideig tartó letartóztatások és ezáltal az Emberi jogok európai egyezménye 5. cikkének ${ }^{57}$ sérelme miatt.

Az EJEB több jelentős ítéletén keresztül dolgozta ki azt a több pontból álló szempontrendszert, amelyet a letartóztatások vonatkozásában vizsgál: 
- annak elengedhetetlen feltétele (conditio sine qua non) a büncselekmény elkövetésének észszerü gyanúja, amely azonban az idő előrehaladtával veszít a jelentöségéböl ${ }^{58}$;

- a letartóztatás meghosszabbítását ezért a nemzeti bíróságoknak az EJEB által relevánsnak és elégségesnek tekintett indokokkal kell alátámasztaniuk ${ }^{59}$; valamint

- az eljárás folyamán valamennyi érintett hatóságnak kellő gondossággal kell eljárnia. ${ }^{60}$

Hazánkkal szemben az EJEE 5. cikke (3) bekezdésének megsértése miatt az első ítélet az Imre kontra Magyarország-ügyben született, amit számos további döntés követett. Ezek lényegi rendelkezéseit az 1. számú táblázat foglalja össze.

A probléma súlyosságát jelzi, hogy a legutóbbi, Lakatos kontra Magyarország-ügyben már felvetődött a pilot judgment eljárás lefolytatásának lehetősége is. Noha a határozathozatal időpontjában (2018. június 26.) hatvan, az egyezmény 5. cikk 3. pontjának megsértésére hivatkozással benyújtott kérelem várt elbírálásra, a bíróság végül úgy foglalt állást, hogy nem állapítható meg strukturális és szisztematikus probléma a magyar jogrendszert, illetve a nemzeti bíróságok gyakorlatát illetően. ${ }^{61}$

\section{A már kiszabott, végrehajtandó szabadságvesztés időtartamának csökkentése}

A büntetés-végrehajtási intézet elhagyásának vannak rövid távứ ${ }^{62}$ és tartós formái. Utóbbiak azok, amelyek érdemben hozzájárulhatnak a telítettség csökkentéséhez. Ezek a feltételes szabadságra bocsátás és a reintegrációs őrizet, amelyeket az Európa Tanács Miniszteri Bizottsága R(92) 16. számú, a közösségi büntetések és intézkedések európai szabályairól szóló ajánlása szerinti közösségi szankcióknak is tekinthetünk. A fogalom azokat a büntetéseket és intézkedéseket foglalja magában, amelyek az elkövetőt a közösségen belül tartják, mindamellett bizonyos feltételek és/vagy kötelezettségek elöírásával egyidejűleg a szabadságát is korlátozzák, ezeket az előírásokat erre a célra rendelt szervek hajtják végre. ${ }^{63} \mathrm{Az} \mathrm{R}(2000) 22$. számú ajánlás úgyszintén a közösségi szankciókhoz sorolja a feltételes szabadságra bocsátást és a mozgásszabadság elektronikus eszközzel történő korlátozását. ${ }^{64}$ 
1. számú táblázat

A letartóztatáshoz kapesolódó EJEB-ítéletek

\begin{tabular}{|c|c|c|}
\hline & $\begin{array}{l}\text { Az ítélethozatal } \\
\text { időpontja }\end{array}$ & Az ítélet legfontosabb megállapításai \\
\hline $\begin{array}{l}\text { A. B. kontra } \\
\text { Magyarország }\end{array}$ & 2013. április 16. & $\begin{array}{l}\text { A megalapozott gyanú tárgyát képező zsarolás bủncselek- } \\
\text { mény tárgyi súlya bár releváns, az idő múlásával nem elég- } \\
\text { séges indoka a letartóztatás meghosszabbításának. }{ }^{65}\end{array}$ \\
\hline $\begin{array}{l}\text { Baksza kontra } \\
\text { Magyarország }\end{array}$ & 2013. április 23. & $\begin{array}{l}\text { A nemzeti bíróságnak a szökés veszélyével kapcsolatban fi- } \\
\text { gyelembe kell vennie a kérelmező megfelelő családi hátterét } \\
\text { és a rendszeres jövedelmét. }{ }^{66}\end{array}$ \\
\hline $\begin{array}{l}\text { Bandur kontra } \\
\text { Magyarország }\end{array}$ & 2016. július 5 . & $\begin{array}{l}\text { A letartóztatás időtartamának észszerüsége nem ítélhető meg } \\
\text { in abstracto, azt a konkrét ügy speciális körülményei alapján } \\
\text { kell megvizsgálni. }{ }^{67}\end{array}$ \\
\hline $\begin{array}{l}\text { Galambos kontra } \\
\text { Magyarország }\end{array}$ & 2015. július 21 . & $\begin{array}{l}\text { Az EJEE 5. cikkének hatálya alá tartozik és szabadságtól } \\
\text { megfosztásnak minősül a házi őrizet (immár bünügyi fel- } \\
\text { ügyelet) is. }{ }^{68}\end{array}$ \\
\hline $\begin{array}{l}\text { Gál kontra } \\
\text { Magyarország }\end{array}$ & 2014. március 11. & $\begin{array}{l}\text { Az eljárás folyamán bekövetkező új fejlemények megköve- } \\
\text { telik az olyan bírósági indokolást, amely kiterjed a letartóz- } \\
\text { tatás ismételt elrendelésének a szükségességére is. }{ }^{69}\end{array}$ \\
\hline $\begin{array}{l}\text { Hagyó kontra } \\
\text { Magyarország }\end{array}$ & 2013. április 23. & $\begin{array}{l}\text { Az EJEE 5. cikke (3) bekezdéséből nem következik olyan, a } \\
\text { részes államokat terhelö kötelezettség, hogy a letartóztatott } \\
\text { személyeket nem megfelelő egészségi állapotukra tekintettel } \\
\text { szabadlábra kellene helyezni. }{ }^{70}\end{array}$ \\
\hline $\begin{array}{l}\text { Hunvald kontra } \\
\text { Magyarország }\end{array}$ & 2013. december 10 . & $\begin{array}{l}\text { İtéletében az EJEB nem tulajdonított jelentőséget a kérelme- } \\
\text { ző egészségi állapotának, mivel a számára szükséges kezelé- } \\
\text { sek a bv. intézetben rendelkezésére álltak, azokat kifejezet- } \\
\text { ten ő utasította el. }{ }^{71}\end{array}$ \\
\hline $\begin{array}{l}\text { Maglódi kontra } \\
\text { Magyarország }\end{array}$ & 2004. november 9 . & $\begin{array}{l}\text { Nem elégséges a kérelmező szökésének veszélyét mindössze } \\
\text { azzal indokolni, hogy a gyanú tárgyává tett emberölés külö- } \\
\text { nös tárgyi súlyú bủncselekmény. }{ }^{72}\end{array}$ \\
\hline $\begin{array}{l}\text { Nagy Gábor kontra } \\
\text { Magyarország }\end{array}$ & 2014. február 11. & $\begin{array}{l}\text { A fogva tartás időtartamát, legyen az bármilyen rövid, a } \\
\text { nemzeti hatóságoknak kell meggyőzően indokolniuk. Az } \\
\text { EJEB ebben az ügyben egy négy hónapig és kilenc napig } \\
\text { tartó letartóztatás észszerütlen hossza miatt marasztalta el } \\
\text { Magyarországot. }{ }^{73}\end{array}$ \\
\hline $\begin{array}{l}\text { Szepesi kontra } \\
\text { Magyarország }\end{array}$ & 2010. december 21. & $\begin{array}{l}\text { Az eljárás során a vádiratot 2004. július 5-én nyújtották be, } \\
\text { ezután az ügy tárgyalása } 2005 \text {. május 9-én kezdődött meg. } \\
\text { A tíz hónapos inaktív periódus összeegyeztethetetlen a nem- } \\
\text { zeti hatóságokat terhelő kellő gondosság követelményével. }{ }^{74}\end{array}$ \\
\hline
\end{tabular}


A feltételes szabadság már a Csemegi-kódex óta ismert jogintézménye a magyar büntetőjognak..$^{75} \mathrm{~A}$ határozott ideig tartó szabadságvesztésből történő feltételes szabadságra bocsátás hatályos feltételeit a Btk. 38-40. §-ai, valamint a bv. kódex 188-190. §-ai tartalmazzák. ${ }^{76}$ Az Európa Tanács Miniszteri Bizottsága R(99) 22. számú, a börtönök túlzsúfoltságáról és a börtönnépesség inflálódásáról szóló ajánlása a feltételes szabadságra bocsátást az egyik leghatékonyabb intézkedésnek tekinti, amely nemcsak csökkenti a tényleges fogva tartás hosszát, hanem elősegíti az elítélt társadalomba való visszailleszkedését is. Ennek ellenére egyes szerzők a kedvezőtlen visszaesési mutatók miatt megalapozatlannak tartják a jogintézmény széles körü alkalmazását. ${ }^{77}$ Úgy gondolom, korántsem helytálló a visszaesők számából azt a következtetést levonni, hogy kevesebb elítéltet kellene feltételesen szabadlábra helyezni. Akik ebben a kedvezményben nem részesülnek, több ideig vannak kitéve a börtönkörnyezet negatív hatásainak, amelyek - ellentétben a feltételes szabadsággal, amely az elítélt társadalomba való visszailleszkedését szolgálná a fogvatartottat éppen az ismételt bünelkövetés irányába terelhetik. Egyetértek Végh Mariannának azzal az állításával, hogy a feltételes szabadság jogintézménye jobban elősegíti a visszaesés megelőzését, mint a büntetés teljes kitöltése. ${ }^{78} \mathrm{~A}$ feltételes szabadságon lévők bünismétlésének és bünözői életvitelének megakadályozására megoldás lehet a pártfogó felügyelet gyakoribb alkalmazása - hiszen azt csak a visszaeső, illetve életfogytig tartó szabadságvesztésre ítélt feltételes szabadságra bocsátása esetén kötelező elrendelni -, valamint annak hatékonyabbá tétele, az elítélt számára elöírt kötelező magatartási szabályok betartásának fokozott felügyelete. Ehhez azonban a pártfogó felügyelők létszámának növelése lenne szükséges, mivel az nem igazodott a növekvő esetszámhoz, az ügyteher miatt pedig nem jut elég idő a szabadságvesztésből szabadultak társadalmi integrációjának elősegítésére. ${ }^{79} \mathrm{Nem}$ a feltételes szabadság gyakori alkalmazása vezet a visszaeséshez, hanem a megfelelő utógondozási rendszer hiánya, amely nélkül a büntetés-végrehajtásban zajló reintegrációs programok sem érnek semmit. ${ }^{80}$

A feltételes szabadság mellett a büntetés-végrehajtási intézet tartós elhagyásának formája a reintegrációs őrizet is. A 2014. évi LXXII. törvénnyel az új bv. kódexbe iktatott jogintézményt célját tekintve a jogalkotó az elítélt társadalomba való visszailleszkedését, valamint a bv. intézetek telítettségének csökkentését elősegítő eszköznek szánta. A 2015. április 1-jei bevezetése után 2015-ben 240 esetben engedélyezte a bv. bíró a reintegrációs őrizet alkalmazását ${ }^{81}$, ez 2016-ban 522 volt. ${ }^{82} \mathrm{~A} \mathrm{Bv}$. tv. 187/A §-ában foglalt feltételrendszer $^{83}$ 2017. január 1-jével módosult annak érdekében, hogy a reintegrációs 
örizetbe helyezhető elítéltek köre bővüljön, mivel az eredetileg megállapított követelményeknek 2015-ös elemzések szerint a teljes fogvatartott közül maximum 300-350 fogvatartott felelt meg; az elörejelzés be is igazolódott. ${ }^{84} \mathrm{~A}$ módosítás folytán immár nemcsak azok részesülhetnek e kedvezményben, akiket első ízben ítéltek végrehajtandó szabadságvesztésre, hanem a visszaesőnek nem minősülő bủnismétlők is, továbbá a 187/A § (1) bekezdésének c) pontja immár csak azt kívánja meg, hogy az elítélt öt évet meg nem haladó tartamú szabadságvesztés-büntetést töltsön, tekintet nélkül annak végrehajtási fokozatára. Ezáltal a büntetésüket fegyházban töltő elítéltek is reintegrációs örizetbe helyezhetök. A bv. intézetek tehermentesítését szolgálja az is, hogy az elítélt számára a korábbi rendelkezéssel ellentétben már nem hat, hanem gondatlan büncselekmény elkövetése miatt kiszabott szabadságvesztés esetén tizenkét, ezen kívül pedig tíz hónapra engedélyezhető a reintegrációs orrizet. ${ }^{85}$

A túlzsúfoltság csökkentésének további eszközei lehetnek még a következők:

- a bv. rendszer maximális feltöltöttségi szintjének elérése esetén egyes országokban korlátozzák vagy megszakítják az újabb befogadásokat, valamint várólistát készítenek azoknak a fogvatartottaknak a felvételéhez, akiknek szabadlábon hagyása nem jelent súlyos biztonsági kockázatot ${ }^{86}$;

- csak rövid távon enyhíti a problémát az amnesztia, amely nemcsak társadalmi feszültséget indukálhat, hanem nemzetközi példák alapján gyors és nagymértékü visszaeséshez vezet, ezért a hatékonysága is megkérdőjelezheto" ${ }^{87}$;

- az új bv. kódex bevezette a szabadságvesztés megkezdése a BVOP felhívása alapján elnevezésü jogintézményt. Ezzel a bv. szervezet közvetlenül hatással lehet a szabadságvesztés végrehajtásával kapcsolatos feladatok ütemezésére $^{88}$, illetve további pozitívuma, hogy a Büntetés-végrehajtás Országos Parancsnoksága a végrehajtás megkezdésére kijelölt bv. intézet kiválasztásánál - több egyéb szempont mellett - figyelembe veszi a telítettséget is.

\section{Összegzés}

A kínzás és az embertelen, megalázó bánásmód tilalma abszolút jellegü emberi jog, annak korlátozása még szükségállapot idején sem lehetséges. Ahhoz, hogy modern, jogállami büntetöjogról beszélhessünk, ennek az emberi jognak át kell hatnia mind a szankciórendszerre vonatkozó jogi szabályozást, mind a szankciók gyakorlati érvényesülését, azok végrehajtását. A büntetőjo- 
gi szankció nem okozhat nagyobb joghátrányt, mint amilyet a bíróság jogerős ítéletében kiszabott.

A szabadságvesztés-büntetés az elítélt személyi szabadságát vonja el. A szankcióból fakadó joghátrány a szabadság elvesztésében áll, ezért hiába is kívánja a közvélemény, hogy az elítélt minél rosszabb körülmények között szenvedjen, ez nem lehet része a büntetésnek. Az elítéltek vonatkozásában tanúsított emberséges bánásmód szükségessége nemcsak a különböző nemzetközi, illetve belső jogi dokumentumokból következik, hanem a józan ész is ezt parancsolja: a bántalmazott, megalázott fogvatartott szabadulása után veszélyesebb, mint az, aki humánus körülmények között töltötte büntetését. ${ }^{89}$

Tanulmányomban igyekeztem minél részletesebben bemutatni azokat a nemzetközi és nemzeti jogi instrumentumokat, amelyek a szabadságvesztés jogi szabályozásával, valamint végrehajtásával kapcsolatos követelményeket fogalmazzák meg. Noha a rendkívül nagy számú kötelező erejü, illetve soft law aktusok szinte mindenre kiterjedően iránymutatást nyújtanak az államok számára, korántsem problémamentes e szankció jogszabályi háttere és végrehajtása. Örvendetes tény, hogy a hazai jogrendszerben immár biztosítottak azok a jogorvoslati lehetőségek, amelyek hatékony eszközül szolgálnak a börtönkörülményeket sérelmezö fogvatartottak számára. A jogalkotó az alapvető jogokat sértő elhelyezési körülmények miatti panasz-, illetve kártalanítási eljárás bevezetése révén eleget tett a Varga és mások kontra Magyarország-ügyben az EJEB által az Emberi jogok európai egyezménye 13. cikkével összefüggésben megfogalmazott felhívásnak. Így a jövőt illetően már „,csak” egy feladat következik a pilotítéletből: az EJEE 3. cikkét sértő elhelyezési körülmények javítása, valamint az embertelen bánásmódot megvalósító túlzsúfoltság enyhítése akár újabb börtönök építése, akár más megoldási módszerek révén.

\section{IRODALOM}

Aebi, Marcelo F. - Tiago, Mélanie M. - Burkhardt, Christine: SPACE I - Council of Europe Annual Penal Statistics: Prison populations, Survey 2015. Council of Europe, Strasbourg, 2015, p. 47. (Updated on 25th of April 2017.)

Bárándy Gergely - Bárándy Alíz: Gondolatok az új Büntető Törvénykönyv elvi jelentőségü rendelkezéseiröl. http://ujbtk.hu/barandy-gergely-phd-barandy-aliz-gondolatok-az-uj-buntetotorvenykonyv-elvi-jelentosegu-rendelkezeseirol/

Becánics Adrienn: Az elítéltekkel való bánásmód kérdései az Emberi Jogok Európai Bírósága gyakorlatában, különös tekintettel a magyar vonatkozású ügyekre. Jogtudományi Közlöny, 2013/9. 
Borbíró Andrea - Szabó Judit: Harmadlagos megelőzés a magyar büntetés-végrehajtási intézetekben a nemzetközi kutatások fényében. In: Vókó György (szerk.): Kriminológiai Tanulmányok 49. Országos Kriminológiai Intézet, Budapest, 2012, 31. o.

http://www.okri.hu/images/stories/KT/KT_49_2012/010_borbiro-szabo.pdf

Bökönyi István: A magyar büntetés-végrehajtás helyzete az Európai Uniós csatlakozás küszöbén. Börtönügyi Szemle, 2003/4.

Csóti András: A büntetőjog változásainak hatása a büntetés-végrehajtási szervezetre, Börtönügyi Szemle, 2011/2.

Csóti András: A magyar bv. intézetek túltelítettsége, a zsúfoltság csökkentésének útjai. Belügyi Szemle, 2015/11.

Elek Balázs: Az előzetes letartóztatás indokolása az Európai Emberi Jogi Bíróság gyakorlatának tükrében. http://ujbtk.hu/dr-elek-balazs-az-elozetes-letartoztatas-indokolasa-az-europaiemberi-jogi-birosag-gyakorlatanak-tukreben/

Elek Balázs: Fogvatartottak körülményeivel kapcsolatos marasztalások az Emberi Jogok Európai Bírósága gyakorlatában. In: Elek Balázs (szerk.): Együttmüködési lehetőségek a büntetés-végrehajtás területén. Printart-Press Kft., Debrecen, 2017, 8-23. o.

Gönczöl Katalin: Csökkenthetö-e a magyar börtönnépesség? A magyar büntetőpolitika a 80as években. Esély, 1990/5.

Görgényi Ilona - Gula József - Horváth Tibor - Jacsó Judit - Lévay Miklós - Sántha Ferenc - Váradi Erika: Magyar büntetöjog. Általános rész. CompLex Kiadó, Budapest, 2014

Hati Csilla: A büntetéskiszabási szemlélet alakulása - a büntető kódex folyamatos módosításának tükrében. http://www.debrecenijogimuhely.hu/archivum/3_2012/a_bunteteskiszabasi_ szemlelet_alakulasa_a_bunteto_kodex_folyamatos_modositasanak_tukreben/

Huszár László - Tari Ferenc: Folyamat. A humánus büntetés-végrehajtás peremfeltételei. Börtönügyi Szemle, 1997/4.

Lajtár József: A zsúfoltság csökkentésének gyakorlati megoldásai. Belügyi Szemle, 2015/11. Matusik Tamás: Gondolatok az előzetes letartóztatás hazai gyakorlatát ért kritikák kapcsán. Magyar Jog, 2015/5.

Nagy Anita: Közösségi szankciók a büntetés-végrehajtásban. In: Róth Erika (szerk.): Decem anni in Europaea Unione V.: tanulmányok a bünügyi tudományok köréből. Miskolci Egyetemi Kiadó, Miskolc, 2016, 98-101. o.

Nagy Ferenc - Juhász Zsuzsanna: A fogvatartotti rátáról nemzetközi összehasonlításban. Börtönügyi Szemle, 2010/3.

Nagy Ferenc: A szabadságelvonással járó szankciókról az új Btk.-ban. Börtönügyi Szemle, 2014/4.

Pallo József: Új horizontok a büntetés-végrehajtási jogban. In: Hack Péter (szerk.): Kodifikációs kölcsönhatások: tanulmányok Király Tibor tiszteletére. ELTE Eötvös Kiadó, Budapest, 2016, 241. o.

Polgár András: Gondolatok a feltételes szabadságra bocsátásról. A jogintézmény fogalma, célja, funkciói. Börtönügyi Szemle, 2014/2.

Sárdi Miklós: Zsúfoltság. Börtönügyi Szemle, 1995/2.

Szabó Krisztián: Gondolatok az előzetes letartóztatás gyakorlatáról. Magyar Jog, 2014/12. 
Végh Marianna: A feltételes szabadság és a reintegrációs őrizet mint a reintegráció elemei. In: Hack Péter (szerk.): Kodifikációs kölcsönhatások: tanulmányok Király Tibor tiszteletére. ELTE Eötvös Kiadó, Budapest, 2016, 262. o.

\section{JOGFORRÁSOK}

Magyarország Alaptörvénye

2017. évi XC. törvény a büntetőeljárásról

2016. évi CX. törvény a büntetések, az intézkedések, egyes kényszerintézkedések és a szabálysértési elzárás végrehajtásáról szóló 2013. évi CXL. törvény és ehhez kapcsolódóan más törvények módosításáról

2014. évi LXXII. törvény a büntetések, az intézkedések, egyes kényszerintézkedések és a szabálysértési elzárás végrehajtásáról szóló 2013. évi CCXL. törvény és ehhez kapcsolódóan más törvények módosításáról

2013. évi CCXL. törvény a büntetések, az intézkedések, egyes kényszerintézkedések és a szabálysértési elzárás végrehajtásáról

2012. évi C. törvény a Büntető Törvénykönyvröl

2010. évi LVI. törvény a Büntető Törvénykönyvről szóló 1978. évi IV. törvény módosításáról 2009. évi LXXX. törvény a Büntető Törvénykönyvről szóló 1978. évi IV. törvény módosításáról

2003. évi II. törvény a büntető jogszabályok és a hozzájuk kapcsolódó egyes törvények módosításáról

1998. évi XIX. törvény a büntetőeljárásról

1978. évi IV. törvény a Büntető Törvénykönyvröl

24/2016. (XII. 23.) IM rendelet egyes büntetés-végrehajtási tárgyú igazságügyi miniszteri rendeletek módosításáról

16/2014. (XII. 19.) IM rendelet a szabadságvesztés, az elzárás, az előzetes letartóztatás és a rendbírság helyébe lépő elzárás végrehajtásának részletes szabályairól

12/2010. (XI. 9.) KIM rendelet a szabadságvesztés és az előzetes letartóztatás végrehajtásának szabályairól szóló 6/1996. (VII. 12.) IM rendelet módosításáról

6/1996. (VII. 12.) IM rendelet a szabadságvesztés és az előzetes letartóztatás végrehajtásának szabályairól

1125/2016. (III. 10.) Korm. határozat a büntetés-végrehajtási intézetek férőhely-bővítéséhez szükséges források biztosításáról

268/2016. (VIII. 31.) Korm. rendelet a büntetés-végrehajtási intézetek férőhely-bővítési programjához kapcsolódó, az új börtönépítési beruházásokkal összefüggő közigazgatási hatósági ügyek nemzetgazdasági szempontból kiemelt jelentőségü üggyé nyilvánításáról

1040/2011. (III. 9.) Kormányhatározat a büntetés-végrehajtási intézetek nemzetközi elvárásoknak való megfelelésével összefüggő átfogó vizsgálat megállapításaihoz kapcsolódó intézkedésekről

2147/2002. (V.10.) Kormányhatározat a büntetés-végrehajtás fejlesztési programjáról 
2072/1998. (III. 31.) Kormányhatározat a büntetés-végrehajtás intézetrendszerének hosszú távú fejlesztéséröl

6/1990. (IK. Bv. Mell. 1.) IM utasítás a 101/1981. (IK. 2.) IM utasítás módosításáról

101/1981. (IK. 2.) IM utasítás Büntetés-végrehajtási Szabályzat végrehajtásáról

32/2014. (XI. 3.) Alkotmánybírósági határozat

30/2013. (X. 28.) Alkotmánybírósági határozat

13/2001 (V. 14.) Alkotmánybírósági határozat

684/B/2001. Alkotmánybírósági határozat

Az alapvető jogok biztosának jelentése az AJB-2987/2012. számú ügyben

\section{LÁBJEGYZETEK}

1 A tanulmány az Országos Bírósági Hivatal Mailáth György Tudományos Pályázata keretében I. dijban részesülő dolgozat alapján készült.

2 Görgényi Ilona - Gula József - Horváth Tibor - Jacsó Judit - Lévay Miklós - Sántha Ferenc - Váradi Erika: Magyar büntetőjog. Általános rész. CompLex Kiadó, Budapest, 2014, 334. o.

3 Emberi jogok európai egyezménye (a továbbiakban: EJEE) 7. cikk.

4 EJEE, Hetedik Kiegészítő Jegyzőkönyv 4. cikk; alaptörvény XXVIII. cikk (6) bekezdés.

5 EJEE 2. cikk, alaptörvény II. cikk.

6 EJEE 3. cikk, alaptörvény III. cikk.

7 Számos más nemzetközi egyezményben megtalálható ez a tilalom: Emberi jogok egyetemes nyilatkozata 5. cikk, Polgári és politikai jogok nemzetközi egyezségokmánya 7. cikk, Emberi jogok amerikai egyezménye 5. cikk. Egyes nemzetközi egyezményeket kifejezetten e tilalom érvényre juttatása érdekében fogadtak el, ilyenek például az ENSZ 1984-es kínzás elleni egyezménye, vagy az Európa Tanács 1987-ben kelt, a kínzás és az embertelen vagy megalázó büntetések vagy bánásmód megelőzéséröl szóló egyezménye.

8 T. P. és A. T. kontra Magyarország. Emberi Jogok Európai Bírósága (a továbbiakban: EJEB vagy ECtHR), 2016. október 4-i ítélet (ügyszámok: 37871/14., 73986/14.).

9 Csüllög kontra Magyarország. ECtHR, 2011. június 7-i ítélet (ügyszám: 30042/08.).

10 P. M. kontra Magyarország. Emberi Jogok Európai Bizottsága (a továbbiakban: ECHR), 1998. szeptember 9-i jelentés (ügyszám: 23636/94.); Z. H. kontra Magyarország. ECtHR, 2012. november 8-i ítélet (ügyszám: 28973/11.).

11 Lásd bővebben Sárdi Miklós: Zsúfoltság. Börtönügyi Szemle, 1995/2., 65-67. o.

12 A 2072/1998. (III. 31.) kormányhatározat, és a hozzá kapcsolódó, a büntetés-végrehajtás fejlesztési programjáról szóló 2147/2002. (V. 10.) kormányhatározat hét „előzetesház”, egy női börtön és egy regionális fiatalkorú-intézet létesítését írta elö. Bökönyi István: A magyar büntetés-végrehajtás helyzete az Európai Uniós csatlakozás küszöbén. Börtönügyi Szemle, 2003/4., 75. o.

13 A Büntetés-végrehajtási Szervezet Évkönyvei 2005-től kezdődően érhetők el, az ezt megelőző időszakra vonatkozó adatok a CPT jelentéseiből származnak.

http://bv.gov.hu/evkonyv; http://www.cpt.coe.int/en/states/hun.htm

14 Report to the Hungarian Government on the visit to Hungary carried out by the European Committee for the Prevention of Torture and Inhuman or Degrading Treatment or Punishment (CPT) from 24 March to 2 April 2009 (a továbbiakban: CPT Report 2009), 54. pont; Conclusions and recommendations of the Committee against Torture. 2007. február 6., CAT/C/Hun/CO/4, 13. pont. Az elhelyezhető létszámot növelő, ezáltal pedig a probléma súlyosságát látszólag enyhítő lépésként a 12/2010. (XI. 9.) KIM rendelet módosította a szabadságvesztés és az előzetes letartóztatás végrehajtásának sza- 
bályairól szóló 6/1996. (VII. 12.) IM rendeletet. A módosítással kapcsolatos alkotmánybírósági döntést a későbbiekben ismertetem.

15 Az EJEB elítéltekkel kapcsolatos ítélkezési gyakorlatáról lásd bővebben Becánics Adrienn: Az elítéltekkel való bánásmód kérdései az Emberi Jogok Európai Bírósága gyakorlatában, különös tekintettel a magyar vonatkozású ügyekre. Jogtudományi Közlöny, 2013/9., 415-424. o.; Elek Balázs: Fogvatartottak körülményeivel kapcsolatos marasztalások az Emberi Jogok Európai Bírósága gyakorlatában. In: Elek Balázs (szerk.): Együttmüködési lehetöségek a büntetés-végrehajtás területén. Printart-Press Kft., Debrecen, 2017, 8-23. o. Az Ananyev-teszt alapján erősen vélelmezhető a megalázó bánásmód, ha a) az elítéltnek nincs saját ágya a zárkában; b) az egy före jutó mozgástér kevesebb, mint három négyzetméter; c) az elítéltek nem tudnak szabadon mozogni a zárkában a berendezési tárgyak között. Három és négy négyzetméter közötti mozgástér esetén olyan további körülményeket értékel az EJEB, mint a nem megfelelő szellőzés és világítás, a mosdóhelyiségek állapota vagy a szabad levegőn való tartózkodás hossza. Ananyev és mások kontra Oroszország. ECtHR, 2012. január 10-i ítélet (ügyszámok: 42525/07., 60800/08.) 148-149. pont.

16 EJEE, 35. cikk 1. pont.

17 A kérelmező a nemzeti bíróságokhoz is hiába fordult volna, hiszen a hazai bírósági gyakorlatban az az álláspont alakult ki, hogy a bv. intézetek túltelítettsége miatt a fogvatartottak felróhatóság hiányában kárigényt nem érvényesíthetnek, hiszen a bv. intézeteket objektív befogadási kötelezettség terheli. Ezáltal az elítéltek legfeljebb a személyiségvédelem felróhatóságtól független szankcióit érvényesíthetik. Lásd például BDT2011.2404.: A büntetés-végrehajtási intézetnek nincs mérlegelési joga az intézetbe beszállított elítéltek befogadása tárgyában, ezért a büntetés-végrehajtási intézet túltelítettsége miatt ellene kártérítési igény felróhatóság hiányában nem érvényesíthető. BDT2013.2969.: Nem felróható a bv. intézet eljárása, ha a jogszabályban elöírt alapfeladatainak csak úgy képes eleget tenni, hogy a fogvatartottak elhelyezésével kapcsolatos egyes szabályokat megszegi.

18 A CPT standardjai alapján egyszemélyes zárkában legalább hat, többszemélyes zárkában legalább négy négyzetméter mozgásteret kell biztosítani a fogvatartottaknak azzal, hogy ebbe nem számítható bele a mosdóhelyiség által elfoglalt hely. Living space per prisoner in prison establishments: CPT standards, p. 1. https://rm.coe.int/16806cc449

19 Szél kontra Magyarország. ECtHR, 2011. június 7-i ítélet (ügyszám: 30221/06.) 11-19. pont.

20 Kovács Gábor István kontra Magyarország. ECtHR, 2012. január 17-i ítélet (ügyszám: 15707/10.) 21-27. pont. További, a Varga-ítéletet megelőző döntésként hozható még fel a Fehér kontra Magyarország-ügy, amelynek tényállása szerint a kérelmező Szolnokon, Tökölön, Állampusztán, Tiszalökön és Budapesten is raboskodott, valamennyi börtönben zsúfolt körülmények között. Ezek közül a JászNagykun-Szolnok Megyei Bv. Intézetet emelte ki a bíróság, ahol személyenként mindössze 1,7 négyzetméter mozgásteret tudtak biztosítani, és a kérelmező állítása szerint csak egy órát tölthetett a zárkáján kívül, míg a többi létesítményben a mozgástér és a zárkán kívül töltött időtartam is kedvezőbb volt. Az ítélet ebben az esetben is elmarasztalta Magyarországot. Fehér kontra Magyarország. ECtHR, 2013. július 2-i ítélet (ügyszám: 69095/10.) 15-23. pont.

21 Report to the Hungarian Government on the visit to Hungary carried out by the European Committee for the Prevention of Torture and Inhuman or Degrading Treatment or Punishment (CPT) from 3 to 12 April 2013 (a továbbiakban: CPT Report 2013), 37. pont.

$22 \mathrm{~A}$ bánásmód általános mércéjével kapcsolatban az $\mathrm{AB}$ több korábbi határozatában is rögzítette, hogy „, az elitélt nem tárgya a büntetés-végrehajtásnak, hanem alanya, akinek jogai és kötelezettségei vannak" [13/2001 (V. 14.) AB határozat; 30/2013. (X. 28.) AB határozat].

23 Noha egy példát mégis megemlít az Alkotmánybíróság: a 684/B/2001. AB határozat szerint nem ütközik a kegyetlen, embertelen, megalázó bánásmód tilalmába az a szabályozás, amely elöírja a fogvatartottak kötelező részvételét a büntetés-végrehajtási intézet tisztántartásában, ellátásában.

24 Az Alkotmánybírósághoz benyújtott indítvány nem érintette a 6/1996. (VII. 12.) IM rendelet 137. § (3) bekezdését, amelyet az (1) bekezdéshez hasonlóan a 12/2010. (XI. 9.) KIM rendelet a következö- 
képpen módosított: „,egyéni elhelyezés esetén a zárka (lakóhelyiség) alapterületének lehetöleg el kell érni a hat négyzetmétert". Ebben az esetben is problémát jelentett a „legalább” helyett a „lehetőleg” kifejezés használata, hiszen az indítványozó az ugyanilyen szövegezésü (1) bekezdés kapcsán úgy fogalmazott, hogy az alapján ad absurdum az sem lenne jogellenes, ha a jogalkalmazó teljesen megvonná a mozgásteret a fogvatartottaktól. A 16/2014. (XII. 19.) IM rendelet az egyéni elhelyezés esetén biztosítandó mozgásteret is kógens jelleggel szabályozta: „, a zárka vagy lakóhelyiség alapterületének el kell érnie a hat négyzetmétert".

25 16/2014. (XII. 19.) IM rendelet, 121. § (1) bek. Megjegyzendö, hogy a 24/2016. (XII. 23.) IM rendelet módosította a 121. §-t, méghozzá oly módon, hogy az az előzö lábjegyzetekben ismertetett CPT-standardoknak immár tökéletesen megfelel, mindamellett a berendezési tárgyakkal kapcsolatos rendelkezést a jogalkotó mellőzte. „,121. § (1) A zárkában vagy a lakóhelyiségben elhelyezhetö létszámot úgy kell meghatározni, hogy minden elitéltre hat köbméter légtér és egyéni elhelyezés esetén legalább hat, közösen elhelyezett elitéltek esetén személyenként legalább négy négyzetméter élettér jusson. (2) Az élettér kiszámitásakor a zárka vagy a lakóhelyiség alapterületéböl az illemhely és a mosdó által elfoglalt területet - függetlenül attól, hogy ezek leválasztása megtörtént-e - figyelmen kívül kell hagyni."

26 Varga és mások kontra Magyarország. ECtHR, 2015. március 10-i ítélet (ügyszámok: 14097/12., 45135/12., 73712/12., 34001/13., 44055/13., 64586/13.).

27 Varga és mások kontra Magyarország. 79-92., 101-105. pont. A Varga-ítélet után még egy esetben, a Gégény kontra Magyarország-ügyben marasztalta el hazánkat az EJEB a 3. cikk megsértése miatt. Gégény kontra Magyarország. ECtHR, 2015. július 16-i ítélet (ügyszám: 44753/12.).

28 Az ekkor már hatályos 16/2014. (XII. 19.) IM rendelet.

29 Például Debreceni Ítélőtábla Pf.I.20.609/2016/4.; Győri Ítélőtábla Pf.V.20.094/2016/3.; Győri Ítélőtábla Pf.V.20.143/2016/4.; Győri Ítélőtábla Pf.III.20.149/2016/4.; Győri Íttélőtábla Pf.V.20.118/2016/4.; Győri Ítélőtábla Pf.V.20.107/2016/4.; Pécsi Ítélőtábla Pf.VI.20.023/2016/4.; Pécsi Ítélőtábla Pf.VI.20.076/2016/3.; Pécsi Ítélőtábla Pf.VI.20.049/2016/4.; Pécsi Ítélőtábla Pf.VI.20.036/2016/5.; Pécsi Ítélőtábla Pf.VI.20.033/2016/5.; Pécsi Ítélőtábla Pf.VI.20.066/2016/4.; Pécsi Ítélőtábla Pf.VI.20.050/2016/5.; Pécsi Ítélőtábla Pf.VI.20.037/2016/5.; Pécsi Ítélőtábla Pf.VI.20.054/2016/5.; Pécsi Ítélőtábla Pf.VI.20.086/2016/3.; Szegedi Ítélőtábla Pf.I.20.764/2016/9.

30 Például Debreceni Törvényszék P.20.378/2016/46.; Győri Törvényszék P.20.167/2017/4.; Kaposvári Törvényszék P.20.624/2016/29.; Nyíregyházi Törvényszék P.20.690/2017/12.; Pécsi Törvényszék P.20.337/2017/18.; Veszprémi Törvényszék P.20.399/2016/18/I.; Veszprémi Törvényszék P.20.236/2015/73/I.; Veszprémi Törvényszék P.20.637/2016/26/I.; Veszprémi Törvényszék P.20.398/2016/24/I.; Veszprémi Törvényszék P.20.652/2017/5/I.; Veszprémi Törvényszék P.21.555/2016/6.

31 Domján kontra Magyarország. ECtHR, 2017. november 14-i határozat (ügyszám: 5433/17.).

32 A férőhelybővítési programot a büntetés-végrehajtási intézetek nemzetközi elvárásoknak való megfelelésével összefüggő átfogó vizsgálat megállapításaihoz kapcsolódó intézkedésekről szóló 1040/2011. (III. 9.) kormányhatározat hirdette meg. A beépítésre szánt ingatlanok kiválasztása után az 1125/2016. (III. 10.) kormányhatározat rendelkezett a férőhelybővítéshez szükséges források biztosításáról, majd a 268/2016. (VIII. 31.) kormányrendelet az új börtönépítési beruházásokkal összefüggő közigazgatási hatósági ügyeket nemzetgazdasági szempontból kiemelt jelentőségü üggyé nyilvánította.

$33 \mathrm{http} / / /$ www.helsinki.hu/bortonzsufoltsag-magyarorszagon/

34 A regisztrált büncselekmények és elkövetőik. http://www.ksh.hu/docs/hun/xstadat/xstadat eves/i_zjb002.html. Természetesen nem hagyható figyelmen kívül a regisztrált bủncselekmények számának alakulását illetően egyes cselekmények kriminalizálása vagy dekriminalizálása, amelyben ugyancsak az állami büntetőpolitika fejeződik ki.

$35 \mathrm{http} / /$ ted.europa.eu/udl?uri=TED\%3ANOTICE\%3A173893-2017\%3ATEXT\%3AHU\%3AHTML $\& \mathrm{src}=0 \#$ id 64175 -II.

36 https://ted.europa.eu/udl?uri=TED:NOTICE:102544-2018:TEXT:HU:HTML\&src=0 
37 Az Európa Tanács Miniszteri Bizottsága Rec(2006) 2. számú ajánlása az Európai Börtönszabályokról. 38 Gönczöl Katalin már egy 1990-ben megjelent cikkében az alternatív büntetési formák szélesebb körú alkalmazásának szükségességére hívta fel a figyelmet a börtönnépesség csökkentésének megoldásaként. Gönczöl Katalin: Csökkenthető-e a magyar börtönnépesség? A magyar büntetőpolitika a 80-as években. Esély, 1990/5., 67. o.

39 A jogerős határozattal befejezett büntetőeljárások felnőtt korú terheltjeinek megoszlása a föbüntetés felfüggesztése és nemek szerint (2016. év - országos). https://birosag.hu/sites/default/files/allomanyok/statisztika2/a_jogeros_hatarozattal_befejezett_buntetoeljarasok_felnott_koru_terheltjeinek_megoszlasa_a_fobuntetes_felfuggesztese_es_nemek_szerint_2016._ev_-_orszagos.pdf ; A jogerös határozattal befejezett büntetőeljárások felnőtt korú terheltjeinek száma és megoszlása a föbüntetés és nemek szerint (2016. év - országos).

https://birosag.hu/sites/default/files/allomanyok/statisztika2/a jogeros hatarozattal befejezett buntetoeljarasok_felnott_koru_terheltjeinek_szama_es_megoszlasa_a_fobuntetes_es_nemek_szerint_201 6. ev_- orszagos 0.pdf

40 A 47 tagállamból a következők előzik meg hazánkat: Albánia, Azerbajdzsán, Csehország, Észtország, Grúzia, Lettország, Litvánia, Moldova, Lengyelország, Oroszország, Szlovákia, Törökország. Marcelo F. Aebi - Mélanie M. Tiago - Christine Burkhardt: SPACE I - Council of Europe Annual Penal Statistics: Prison populations, Survey 2015. Council of Europe, Strasbourg, 2015, p. 47. (Updated on 25th of April 2017.)

$41 \mathrm{Az}$ említett 12 államból kettö, Litvánia és Törökország tekintetében nem áll rendelkezésre adat arra vonatkozóan, hogy mekkora az egy fogvatartottra jutó átlagos mozgástér nagysága.

42 Észtországban és Lengyelországban pontosan 3, Moldovában 3,4, Szlovákiában 3,5 m2 az egy fogvatartottra eső mozgástér. Marcelo F. Aebi - Mélanie M. Tiago - Christine Burkhardt: i. m. 34. o.

43 Megjegyzendö ugyanakkor, hogy 47-böl 12 tagállam nem szolgáltatott erre vonatkozóan adatot. Marcelo F. Aebi - Mélanie M. Tiago - Christine Burkhardt: i. m. 34. o.

44 Uo.

45 Nagy Ferenc - Juhász Zsuzsanna: A fogvatartotti rátáról nemzetközi összehasonlításban. Börtönügyi Szemle, 2010/3., 9-10. o.

46 2003. évi II. törvény 88 . § (1) bekezdés e) pont.

47 A 2003. évi II. törvény általános indokolása, I. pont.

48 Hati Csilla: A büntetéskiszabási szemlélet alakulása - a büntető kódex folyamatos módosításának tükrében.

http://www.debrecenijogimuhely.hu/archivum/3_2012/a_bunteteskiszabasi_szemlelet_alakulasa a_bunteto_kodex_folyamatos_modositasanak_tukreben/

49 Lásd 3. számú ábra.

50 Nagy Ferenc: A szabadságelvonással járó szankciókról az új Btk.-ban. Börtönügyi Szemle, 2014/4., 1. o.; Bárándy Gergely - Bárándy Alíz: Gondolatok az új Büntető Törvénykönyv elvi jelentöségủ rendelkezéseiröl. http://ujbtk.hu/barandy-gergely-phd-barandy-aliz-gondolatok-az-uj-bunteto-torvenykonyv-elvi-jelentosegu-rendelkezeseirol/

51 Csóti András: A büntetőjog változásainak hatása a büntetés-végrehajtási szervezetre, Börtönügyi Szemle, 2011/2., 1. o.

52 Börtönstatisztikai Szemle, 2016/1., 8. o.; Börtönstatisztikai Szemle, 2018/1., 7. o.

53 Csóti András: i. m. 6. o.

54 Noha mind az Emberi Jogok Európai Bírósága hivatkozott ítéletei, mind a statisztikai adatok a büntetőeljárásról szóló 2017. évi XC. törvény 2018. július 1. napján történt hatálybalépése előtti időszakra vonatkoznak, tanulmányomban már az új Be. által bevezetett letartóztatás megnevezést használtam a kényszerintézkedés tekintetében.

55 Az Európa Tanács Miniszteri Bizottsága R(80) 11. számú ajánlása az ítélethozatalt megelőző fogva tartásról. 
56 Lásd például Szabó Krisztián: Gondolatok az előzetes letartóztatás gyakorlatáról. Magyar Jog, 2014/12., 725-729. o.; Matusik Tamás: Gondolatok az előzetes letartóztatás hazai gyakorlatát ért kritikák kapcsán. Magyar Jog, 2015/5., 289-293. o.

57 „Mindenkinek joga van a szabadságra és a személyi biztonságra. Szabadságától senkit sem lehet megfosztani, kivéve az alábbi esetekben és a törvényben meghatározott eljárás útján: [...] c) törvényes letartóztatás vagy őrizetbe vétel abból a célból, hogy e bűncselekmény elkövetésének alapos gyanúja miatt az illetékes hatóság elé állítsák, vagy amikor ésszerü oknál fogva szükséges, hogy megakadályozzák büncselekmény elkövetésében vagy annak elkövetése után a szökésben."

58 Stögmüller kontra Ausztria. ECtHR, 1969. november 10-i ítélet (ügyszám: 1602/62.)

59 Wemhoff kontra Németország. ECtHR, 1968. június 27-i ítélet (ügyszám: 2122/64.), Neumeister kontra Ausztria. ECtHR, 1968. június 27-i ítélet (ügyszám: 1936/63.)

60 Lásd bővebben Elek Balázs: Az előzetes letartóztatás indokolása az Európai Emberi Jogi Bíróság gyakorlatának tükrében. http://ujbtk.hu/dr-elek-balazs-az-elozetes-letartoztatas-indokolasa-az-europaiemberi-jogi-birosag-gyakorlatanak-tukreben/

61 Lakatos kontra Magyarország. ECtHR, 2018. június 26-i ítélet (ügyszám: 21786/15.) 84-91. pont.

62 Ezek a látogató bv. intézeten kívüli fogadása (2013. évi CCXL. törvény 178. §), a kimaradás (179. §) és az eltávozás $(180 . \S)$. Említést érdemel még, hogy a 187. §-ban meghatározott társadalmi kötődés programban részt vevő elítélt jogosult felügyelet nélkül külső munkahelyen dolgozni, valamint tanulmányokat és képzéseket folytatni a bv. intézeten kívül.

63 Európa Tanács Miniszteri Bizottsága R(92) 16. számú ajánlása, Melléklet 1. pont.

64 Európa Tanács Miniszteri Bizottsága R(2000) 22. számú ajánlása, II. számú melléklet 1. pont.

65 A. B. kontra Magyarország. ECtHR, 2013. április 16-i ítélet (ügyszám: 33292/09.) 25. pont.

66 Baksza kontra Magyarország. ECtHR, 2013. április 23-i ítélet (ügyszám: 59196/08.) 36. pont.

67 Bandur kontra Magyarország. ECtHR, 2016. július 5-i ítélet (ügyszám: 50130/12.) 60. pont. Lásd még

Süveges kontra Magyarország. ECtHR, 2016. január 5-i ítélet (ügyszám: 50255/12.)

68 Galambos kontra Magyarország. ECtHR, 2015. július 21-i ítélet (ügyszám: 13312/12.) 19. pont.

69 Gál kontra Magyarország. ECtHR, 2014. március 11-i ítélet (ügyszám: 62631/11.) 47. pont.

70 Hagyó kontra Magyarország. ECtHR, 2013. április 23-i ítélet (ügyszám: 52624/10.) 57. pont. Lásd még X. Y. kontra Magyarország. ECtHR, 2013. március 19-i ítélet (ügyszám: 43888/08.)

71 Hunvald kontra Magyarország. ECtHR, 2013. december 10-i ítélet (ügyszám: 68435/10.) 41. pont.

72 Maglódi kontra Magyarország. ECtHR, 2004. november 9-i ítélet (ügyszám: 30103/02.) 39. pont.

73 Nagy Gábor kontra Magyarország. ECtHR, 2014. február 11-i ítélet (ügyszám: 33529/11.) 25. pont

74 Szepesi kontra Magyarország. ECtHR, 2010. december 21-i ítélet (ügyszám: 7983/06.) 28. pont.

75 Nagy Anita: Közösségi szankciók a büntetés-végrehajtásban. In: Róth Erika (szerk.): Decem anni in Europaea Unione V.: tanulmányok a bünügyi tudományok köréből. Miskolci Egyetemi Kiadó, Miskolc, 2016, 98-101. o.

76 Ezekről lásd bővebben Nagy Anita: i. m. 101-104. o.

77 Polgár András: Gondolatok a feltételes szabadságra bocsátásról. A jogintézmény fogalma, célja, funkciói. Börtönügyi Szemle, 2014/2., 5. o.

78 Végh Marianna: A feltételes szabadság és a reintegrációs őrizet mint a reintegráció elemei. In: Hack Péter (szerk.): Kodifikációs kölcsönhatások: tanulmányok Király Tibor tiszteletére. ELTE Eötvös Kiadó, Budapest, 2016, 262. o.

79 Az alapvető jogok biztosának jelentése az AJB-2987/2012. számú ügyben, 53. o.

80 Borbíró Andrea - Szabó Judit: Harmadlagos megelőzés a magyar büntetés-végrehajtási intézetekben a nemzetközi kutatások fényében. In: Vókó György (szerk.): Kriminológiai Tanulmányok 49. Országos Kriminológiai Intézet, Budapest, 2012, 31. o.

http:/www.okri.hu/images/stories/KT/KT_49_2012/010_borbiro-szabo.pdf

81 A Büntetés-végrehajtási Szervezet Évkönyve 2015., 25. o.

82 A Büntetés-végrehajtási Szervezet Évkönyve 2016., 36. o. 
83 Lásd bővebben Végh Marianna: i. m. 265-266. o.

84 Lajtár József: A zsúfoltság csökkentésének gyakorlati megoldásai. Belügyi Szemle, 2015/11., 20. o.

85 2013. évi CCXL. törvény 187/A § (1a) bekezdés.

86 Csóti András: A magyar bv. intézetek túltelítettsége, a zsúfoltság csökkentésének útjai. Belügyi Szemle, 2015/11., 8. o.

87 Uo. 11. o.

88 Pallo József: Új horizontok a büntetés-végrehajtási jogban. In: Hack Péter (szerk.): Kodifikációs kölcsönhatások: tanulmányok Király Tibor tiszteletére. ELTE Eötvös Kiadó, Budapest, 2016, 241. o.

89 Huszár László - Tari Ferenc: Folyamat. A humánus büntetés-végrehajtás peremfeltételei. Börtönügyi Szemle, 1997/4., 27. o. 